American Journal of Agricultural and Biological Sciences 5 (3): 342-349, 2010

ISSN 1557-4989

(C) 2010 Science Publications

\title{
Novel Postharvest Treatment Reduces Ascorbic Acid Losses in Mango (Mangifera indica L.) Var. Kent
}

\author{
${ }^{1}$ Maria A. Islas-Osuna, ${ }^{1}$ Norma A. Stephens-Camacho, ${ }^{1}$ Carmen A. Contreras-Vergara, \\ ${ }^{2}$ Marisela Rivera-Dominguez, ${ }^{3}$ Ernesto Sanchez-Sanchez, \\ ${ }^{1}$ Monica A. Villegas-Ochoa and ${ }^{1}$ Gustavo A. Gonzalez-Aguilar \\ ${ }^{1}$ Department of Vegetable Food Technology, \\ Research Center for Food Research and Development, CIAD, AC, Ejido La Victoria Rd., \\ Km 0.6., P.O. Box 1735, Hermosillo, Sonora, 83000, Mexico \\ ${ }^{2}$ Department of Food Science, \\ Research Center for Food Research and Development, CIAD, AC, Mexico \\ ${ }^{3}$ Research Station Valle del Mayo, National Institute of Forestry, \\ Agricultural and Veterinary Research, INIFAP, \\ Huatabampo Rd. Km 0.9. Navojoa, Sonora, 85300, Mexico
}

\begin{abstract}
Problem statement: Mango is a tropical fruit that ripens very quickly; for this reason, there has been a continuous effort to develop postharvest technologies to extend its shelf life and quality. Among them, 1-Methylcyclopropene (1-MCP) is widely used because it inhibits the action of ethylene receptors. Approach: Changes in physicochemical parameters, bioactive compounds and cell wall degrading activities were evaluated during storage and ripening of fresh whole mangoes treated with 1MCP $\left(750 \mathrm{~nL} \mathrm{~L}^{-1}\right)$. Mature-green mangoes, cultivar Kent, untreated or treated with 1-MCP were evaluated for external quality, phytochemicals, Polygalacturonase (PG) and Pectin Methylesterase (PME) enzymatic activities during storage at $20^{\circ} \mathrm{C}$ for 2 weeks. Results: Concentration of ascorbic acid decreased during fruit ripening but 1-MCP-treated mangoes had reduced losses. Polygalacturonase and pectin methylesterase activities were reduced in the treated fruits as compared to untreated mangoes. Small changes in $\beta$-carotene were observed between treated and untreated fruits. Conclusion: 1-MCP affected the ripening process in "Kent" mango, reducing losses of ascorbic acid, this treatment is justified since it helps to maintain mango's nutritional value during its shelf life.
\end{abstract}

Key words: Mango, 1-MCP, 1-methylcyclopropene, ripening, ascorbic acid

\section{INTRODUCTION}

Ripening of climacteric fruits such as mango (Mangifera indica L.) is followed by a peak in respiration and a concomitant production of ethylene. Ethylene is needed to trigger several ripeningassociated processes, such as changes in color, texture, flavor and aroma of the fruit flesh (Giovannoni, 2004). Ethylene is a plant hormone that regulates many processes of growth and development, including ripening and is also an important mediator of plant responses to biotic and abiotic stresses (Wang et al., 2002). This simple hydrocarbon molecule can diffuse in and out of plant tissues from both endogenous and exogenous (nonbiological and biological) sources (Saltveit, 1999).
Ethylene affects the quality of harvested products and it can be helpful or harmful, depending on the produce and its ripening stage (Saltveit, 1999). Some commercial strategies used to withdraw deleterious effects of ethylene over produce are practiced. For instance, avoid exposure to ethylene, minimize ethylene production and action during produce ripening, harvest, storage and transport (Watkins, 2002). Also, by using compounds that inhibit ethylene action through interaction with ethylene receptors (Sisler and Serek, 1997).

$1-\mathrm{MCP}$ is a synthetic cyclic olefin capable of inhibiting ethylene action. It acts as a competitor of ethylene, blocking its access to the ethylene-binding receptors (Sisler and Serek, 1997). The affinity of 1-

Corresponding Author: Maria A. Islas-Osuna, Department of Vegetable Food Technology,

Research Center for Food Research and Development, CIAD, AC, Ejido La Victoria Rd.. Km 0.6., P.O. Box 1735, Hermosillo, Sonora, 83000, Mexico Tel: (+52 662) 2892400 ext. 526 Fax: (+52 662) 2800422 
MCP for the receptors is approximately 10-times greater than that of ethylene and, therefore, compared with ethylene, thus it is active at much lower concentrations. $1-\mathrm{MCP}$ is a gaseous nontoxic product that delays softening and improves post-storage quality of several climacteric fruits (Blankenship and Dole, 2003) and it is applied to extend their postharvest life. Moreover, 1MCP is being used as a powerful tool to gain insights into fundamental processes that are involved in ripening and senescence, as well as to understand ethylene's action and responses (Watkins, 2006).

The effects of 1-MCP in fruits are variable depending on the fruit. For example, 1-MCP induced an increase in sugars (expressed as soluble solids) in papaya (Hofman et al., 2001) and pineapple (Selvarajah et al., 2001), but reduced sugars in kiwifruit (Boquete et al., 2004) and nectarines (Bregoli et al., 2005). Furthermore, 1-MCP had no effect on soluble solid contents of plums (Menniti et al., 2004) and mamey sapote (Ergun et al., 2005). Organic acids such as citric acid were reduced in 1-MCP-treated apple (Defilippi et al., 2004) and were increased in guava (Bassetto et al., 2005); malic acid in apple did not change due to 1-MCP treatment (Defilippi et al., 2004; Kondo et al., 2005). Respiration rates and ethylene production are reduced in fruits treated with 1-MCP most of the time (Jiang et al., 2001; Dong et al., 2002; Mwaniki et al., 2005).

As for bioactive compounds, ascorbic acid content was higher in 1-MCP treated mango "Tommy Atkins" as compared to the untreated mango (Del Monte et al., 2004). However, there were no significant changes in ascorbic acid content of mango "Guifei" (Wang et al., 2006) and chayote (Cadena-Iniguez et al., 2006) after 1MCP treatment. $\beta$-carotene was little affected in 1-MCP treated "Spring Belle" peach fruits (Caprioli et al., 2009).

Softening is a result of several metabolic changes during maturity and ripening in fruits and vegetables. Softening in climacteric fruit ripening is generally attributed to the degradation of the cell wall, particularly to the solubilization of pectins (Lohani et al., 2004). These ultra structural and chemical changes may be the result of de novo synthesis of cell wall hydrolases, such as Polygalacturonase (PG), Pectin Methylesterase (PME), Pectate Lyase (PL) and cellulose, during fruit ripening (Brummell and Harpster, 2001).

1-MCP delays softening of most fruits, although some crop species are insensitive to this compound (Blankenship and Dole, 2003). For example, 1-MCP effectively delayed softening of banana (Watkins, 2006) and "Tonewase" and "Saijo" persimmon fruits (Harima et al., 2003). Firmness is the measured parameter related to softening; in 1-MCP treated
" $d$ 'Anjou" pear, firmness was higher than in nontreated fruits (Argenta et al., 2003). Better firmness was also observed in several 1-MCP treated fruits, including avocado (Feng et al., 2000), strawberry (Jiang et al., 2001), guavas (Bassetto et al., 2005), plum cultivars (Martinez-Romero et al., 2003), pear (Hiwasa et al., 2003; Ekman et al., 2004), watermelon (Mao et al., 2004), banana (Lohani et al., 2004), kiwifruit (Boquete et al., 2004), apple (Defilippi et al., 2004) and nectarine (Bregoli et al., 2005).

In this context, while PME activity decreases in fruits during ripening, PG activity increases. However, the levels of enzymatic activity of PG and PME were lower in 1-MCP treated banana compared to the untreated fruits (Lohani et al., 2004). In addition, PME provides substrate for PG and together they act mainly on the cell wall middle lamella (Koch and Nevins, 1989). In plums, exo-PG and endo-glucanase activities were lower in 1-MCP treated fruits when compared with untreated fruits; whereas Pectin Esterase (PE) and endo-PG were similar in treated and untreated plums (Dong et al., 2001). Hiwasa et al. (2003) reported that ethylene is required for both initiation and progression of softening in pear fruit and they found that 1-MCP reduced the accumulation of PG1 and PG2 mRNAs of and endo- $\beta$-glucanase in the fruits (Hiwasa et al., 2003). The reduction in accumulation of these transcripts paralleled the pattern of fruit softening. In contrast, in avocado exposed to 1-MCP, PG activity was reduced during ripening and cellulase activity was also low throughout the storage period. Despite the lower enzymatic activities of fruit treated with 1-MCP, they ripen and soften normally (Feng et al., 2000). The aim of this study was to evaluate the effects of 1-MCP application on "Kent" mango fruits over external quality parameters, bioactive compounds and two cellwall degrading enzymatic activities.

\section{MATERIALS AND METHODS}

Plant material and tissue sampling: Mature-green mango (Mangifera indica L. cv. Kent) (180 days after blooming) fruit of uniform size (approximately $500 \mathrm{~g}$ ) were selected and hand harvested from the production region of Bacobampo, Sonora, Mexico (2704'37.96" $\mathrm{N}$ and $109^{\circ} 27^{\prime} 05.56^{\prime \prime} \mathrm{W}$ ) and transported within $12 \mathrm{~h}$ to the laboratory in Hermosillo. Fruits had an average firmness of $137 \mathrm{~N}, 11.9^{\circ}$ Brix and color parameters L $=71.6, \mathrm{a}=2.7$ and $\mathrm{b}=72.5$. Upon arrival, fruits were washed with chlorinated water (200 ppm sodium hypochlorite), air dried and the 1-MCP treatment was applied at $20^{\circ} \mathrm{C}$. 
MCP treatment and storage: A powder containing $0.14 \%$ of $1-\mathrm{MCP}$ as active ingredient was used for fruit treatment (SmartFresh, AgroFresh Rohm and Haas, Philadelphia, PA). Two groups of fruit were treated, as follows: $50 \mathrm{~mL}$ of distilled water at $50^{\circ} \mathrm{C}$ were added to the flask containing a predetermined amount of powder (for untreated fruits, the flask did not contain powder) and was stirred until its complete dissolution, giving a 1MCP concentration of $750 \mathrm{~nL} \mathrm{~L}^{-1}$. 1-MCP application was performed by placing the fruit into hermetic chambers (202-L polyethylene boxes) and exposing them to the gas for $12 \mathrm{~h}$ at $20^{\circ} \mathrm{C}$. After the treatment period, the chambers were opened and fruits were kept at $20^{\circ} \mathrm{C}$ for 2 weeks. At 3-day intervals, fruits were sampled to analyze physicochemical parameters, $\beta$-carotene, ascorbic acid and PG and PME activity.

\section{Physicochemical}

parameters:

Six

fruit/treatment/sampling were used to measure pulp color by means of two readings on opposite sides along the equatorial region of the fruit using a colorimeter (Minolta CR-300, Osaka, Japan). Results were expressed as hue color angle and chroma. After that, weight loss was determined by the difference between the initial and final weights of each replicate using a digital Balance Voyager V0120 (Ohaus, USA). Pulp firmness was determined with a $10 \mathrm{~mm}$ point digital penetrometer (Chatillon DMF50, USA) carrying out two readings per fruit on opposite sides along the equatorial regions and the results were expressed in Newton $(\mathrm{N})$. Sample juice was taken from these fruits to measure Titratable Acidity (TA); $5 \mathrm{~mL}$ of juice diluted with $50 \mathrm{~mL}$ of water was titrated with $0.1 \mathrm{~N} \mathrm{NaOH}$ to $\mathrm{pH}$ 8.2 and expressed as percentage of citric acid, using an automatic titrator (Mettler DLG7, Switzerland). Total Soluble Solids (TSS) concentration was determined by direct reading of mango juice drop in a digital refractometer (Atago PR-101, Atago Co. Ltd., Tokyo, Japan) and results were expressed as ${ }^{\circ}$ Brix.

Respiratory rate and ethylene production: Respiratory rate and ethylene production were evaluated daily, as previously reported (Watada and Massie, 1981), by incubating one fruit of known mass and volume in a $3.98 \mathrm{~L}$ hermetic flask during $1 \mathrm{~h}$. One milliliter of headspace was withdrawn with a syringe and injected to a gas chromatograph Varian Star 3400 (Varian, USA). $\mathrm{CO}_{2}$ and $\mathrm{C}_{2} \mathrm{H}_{4}$ concentration was calculated comparing the peak areas with known standards. Respiratory rate was expressed as $\mathrm{mL} \mathrm{CO}_{2}$ $\mathrm{kg}^{-1} \mathrm{~h}^{-1}$ and ethylene production as $\mu \mathrm{L} \mathrm{C}_{2} \mathrm{H}_{4} \mathrm{~kg}^{-1} \mathrm{~h}^{-1}$.

Bioactive compounds: $\beta$-carotene was determined as described by Mejia et al. (1988) and expressed as milligrams per $100 \mathrm{~g}$ of pulp. Fresh tissue $(1 \mathrm{~g})$ was homogenized (Ultra Turrax T-25 Basic S1, Ika, Werke, USA) at $13500 \mathrm{rpm}$ for $3 \mathrm{~min}$ with $15 \mathrm{~mL}$ of tetrahydrofurane, containing $0.4 \%$ butylated hydroxytoluene. The mixture was centrifuged for 15 min at $14000 \mathrm{rpm}$, filtered through a $0.22 \mu \mathrm{m}$ filter and analyzed by HPLC using a Microsorb RP-C18, $3 \mu \mathrm{m}$ $(4.6 \mathrm{~mm} \times 10 \mathrm{~cm})$ column with a $3 \mathrm{~cm}$ guard column (Supelco, Mexico) and acetonitrile/methanol/tetrahydrofurane (58:35:7) as the mobile phase at a flow rate of $1.0 \mathrm{~mL} \mathrm{~min}$. $\beta$-carotene was detected by ultraviolet absorption at $460 \mathrm{~nm}$.

Ascorbic acid was determined as described by Doner and Hicks (1981). Three samples per treatment were analyzed with a Varian 9012 (Varian, Mexico) liquid chromatography equipped with an L-4000 UV detector and an L-6000 pump. Ascorbic acid was detected using a water- $\mathrm{NH}_{2}$ type ${ }^{\circ}$ Bondapak analytical column $(3.9 \times 300 \mathrm{~mm}, 10 \mu \mathrm{m}), 10 \mu \mathrm{L}$ loop injector. The mobile phase was acetonitrile: $\mathrm{KH}_{2} \mathrm{PO}_{4} 1 \mathrm{M}(75: 25$ $\mathrm{v} / \mathrm{v}$ ), at a flow rate of $1.5 \mathrm{~mL} \mathrm{~min}^{-1}$ and the detector wavelength was set at $268 \mathrm{~nm}$. Ascorbic acid results were expressed in milligrams of ascorbic acid per $100 \mathrm{~g}$ of pulp.

PG activity: PG activity was measured from mango crude extract prepared by homogenizing $10 \mathrm{~g}$ of frozen mango pulp with $20 \mathrm{~mL}$ of $1 \% \mathrm{NaHSO}_{3}$ (pH 6.0) in an Ultra Turrax T25 at $24000 \mathrm{rpm}$ during $1 \mathrm{~min}$. The homogenate was filtered twice and washed with $20 \mathrm{~mL}$ of $1 \% \mathrm{NaHSO}_{3}$, resuspended in $15 \mathrm{~mL}$ of $1 \mathrm{M} \mathrm{NaCl}$ and agitated during $3 \mathrm{~h}$ at $4^{\circ} \mathrm{C}$. The activity was measured as the reducing groups released from polygalacturonic acid (Gross, 1982). Protein concentration was determined in the extracts according to the dye-binding Bradford (1976) assay, using bovine serum albumin as the standard.

PME activity: PME preparation of crude extract enzyme was done according to Wicker et al. (1987). Briefly, frozen mango pulp was homogenized in a 1:5 ratio (w/v) of pulp to $0.25 \mathrm{M}$ Tris-Cl, $0.3 \mathrm{M} \mathrm{NaCl}, \mathrm{pH}$ 8.0 , at high speed for $15 \mathrm{~s}$ using a blender. The mixture was stirred for $1 \mathrm{~h}$ at room temperature and centrifuged at $16.000 \mathrm{~g}$ for $25 \mathrm{~min}$ at $4^{\circ} \mathrm{C}$. The supernatant, constituting the crude enzyme extract, was stored at $-20^{\circ} \mathrm{C}$ in small aliquots until needed. Analyses were conducted in triplicate on the enzyme extract at $25^{\circ} \mathrm{C}$. Briefly, PME activity was measured potentiometrically by measuring free carboxyl groups formed as a result of enzyme action on pectin (Banjongsinsiri et al., 2004). The reaction mixture in the standard method assay consisted of $5 \mathrm{~mL}$ of PME sample and $50 \mathrm{~mL}$ of a $1 \%$ 
citrus pectin solution containing $0.1 \mathrm{M} \mathrm{NaCl}$. During hydrolysis at $30^{\circ} \mathrm{C}$, the $\mathrm{pH}$ was maintained at 7.5 by the addition of $0.045 \mathrm{~N} \mathrm{NaOH}$ using an automatic pHtitrator (Mettler DL25, USA). One unit of PME activity was defined as the amount of enzyme that released 1 $\mu \mathrm{mol}$ of carboxylic acid group per minute.

Statistical analysis: A variance analysis (two-way ANOVA) was performed using STATISTICA 8.0 software (Tulsa, OK, USA) and comparison of the treatments was made by means of Tukey's multiple range test at a significant level of $\mathrm{p} \leq 0.05$.

\section{RESULTS}

Fruit quality, $\mathrm{CO}_{2}$ and ethylene were not affected by the 1-MCP treatment: Skin color and firmness losses are the most appreciable changes that occur in mango fruit at temperatures above $10^{\circ} \mathrm{C}$. These changes depend on the cultivar, storage conditions and postharvest treatment applied to produce. In the present study, the 1MCP treatment applied to "Kent" mango did not affect TA, TSS, firmness, respiratory rate and ethylene production during storage at $20^{\circ} \mathrm{C}$ for 2 weeks (data not shown).

Bioactive compound contents of mango were affected by the 1-MCP treatment: Figure 1 shows that $\beta$-carotene levels decreased and then increased at the end of the storage period ( 2 weeks) in both treated and untreated mangoes. In 1-MCP treated mangoes the $\beta$-carotene levels decreased from 5.5-2 mg $100 \mathrm{~g}^{-1}$ Fresh Weight (FW) then increased to $6.9 \mathrm{mg} 100 \mathrm{~g}^{-1}$ FW by day 15; while untreated mangos started at 4.2 $\mathrm{mg} 100 \mathrm{~g} \mathrm{~g}^{-1} \mathrm{FW}$ then decreased to 2.1 and increased to $6.3 \mathrm{mg} 100 \mathrm{~g}^{-1} \mathrm{FW}$ at the end of the storage period.

Figure 2 shows the Ascorbic Acid (AA) content of mangoes during storage at $20^{\circ} \mathrm{C}$. The AA content in 1MCP treated mangoes did not change significantly during twelve days of storage. Initial AA content of 1-

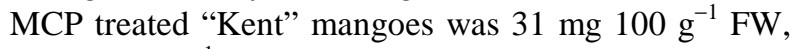
$28 \mathrm{mg} 100 \mathrm{~g}^{-1} \mathrm{FW}$ on day 12 and the final AA content was $20 \mathrm{mg} 100 \mathrm{~g}^{-1} \mathrm{FW}$ at 15 days after treatment. AA content in untreated mangoes started at $30 \mathrm{mg}^{100 \mathrm{~g}^{-1}}$

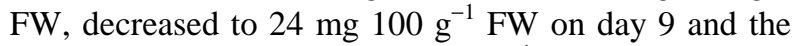
final AA content was $17 \mathrm{mg} 100 \mathrm{~g}^{-1} \mathrm{FW}$ after 15 days of harvest. Even though AA levels in mangoes decreased during storage, 1-MCP treatment prevented ascorbic acid losses from days 1-12, where the differences between treated and untreated mangoes were statistically different $(\mathrm{p} \leq 0.05)$.

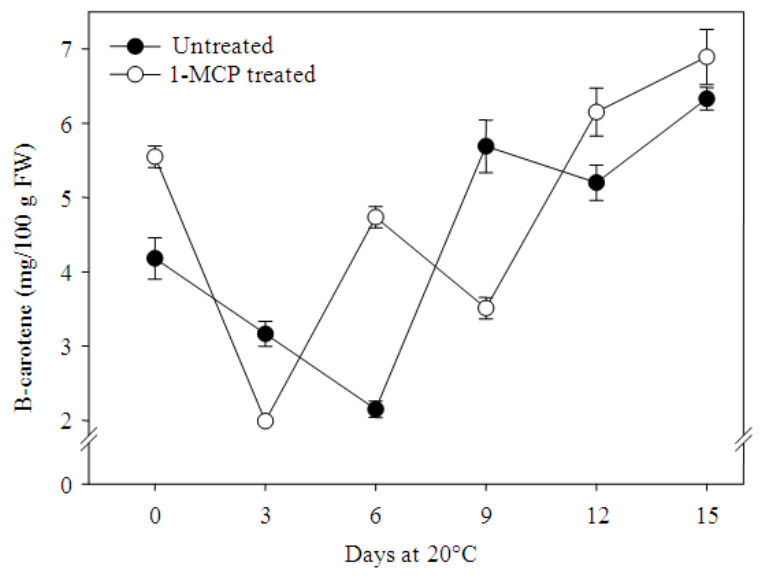

Fig. 1: $\beta$-carotene content of mango pulp untreated and 1 -MCP treated and stored at $20^{\circ} \mathrm{C}$ for 15 days. Data are the mean \pm SE of three replicates

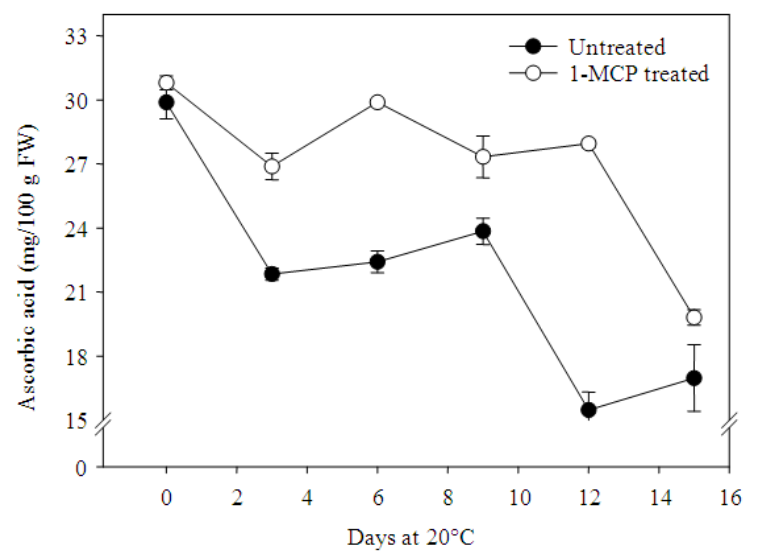

Fig. 2: Ascorbic acid content of mango pulp untreated and 1-MCP treated and stored at $20^{\circ} \mathrm{C}$ for 15 days. Data are the mean $\pm \mathrm{SE}$ of three replicates

PG and PME enzymatic activity: PG and PME are two key enzymes related to softening during fruit ripening. Figure 3 shows the PG activity profile in mango. In this study, PG activity gradually increased in 1-MCP-treated (2.7-6.1 units $\mathrm{mg}^{-1}$ protein) and untreated (3.0-8.2 units $\mathrm{mg}^{-1}$ protein) mangoes during ripening throughout the 15 day period. In $1-\mathrm{MCP}$ treated mangoes PG activity was statistically similar $(p \leq 0.05)$ to PG activity from untreated mangoes during the first 9 days of storage. However, PG activity of treated and untreated mangoes from day 12-15 was statistically different $(\mathrm{p} \leq 0.05)$. After 2 weeks at $20^{\circ} \mathrm{C}$, PG activity for 1-MCP-treated mangoes was 6.1 units $\mathrm{mg}^{-1}$ protein and 8.2 units $\mathrm{mg}^{-1}$ protein for untreated ones. 


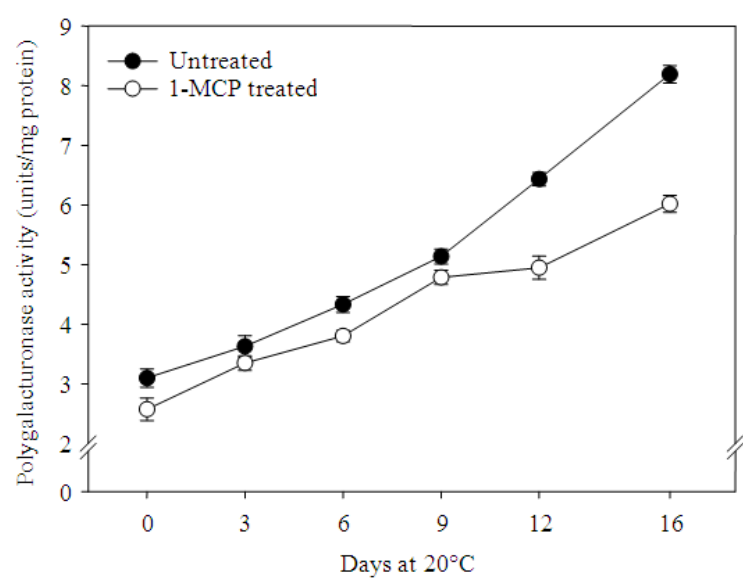

Fig. 3: PG activity from the pulp of mango "Kent" harvested at the mature green stage, treated with $1-\mathrm{MCP}$ and stored at $20^{\circ} \mathrm{C}$ during 15 days. Data are the mean $\pm \mathrm{SE}$ of three replicates

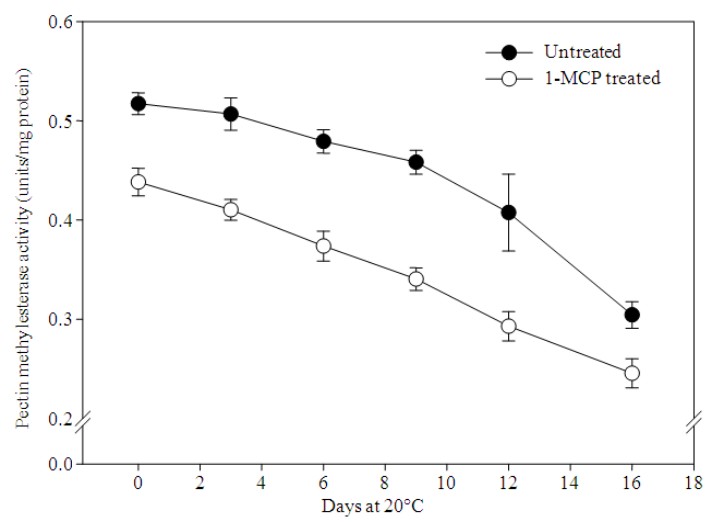

Fig. 4: PME activity of mango "Kent" harvested at the mature green stage, treated with 1-MCP and stored at $20^{\circ} \mathrm{C}$ during 15 days. Data are the mean $\pm \mathrm{SE}$ of three replicates

The PME activity profile is shown in Fig. 4; it gradually decreased in both treated and untreated mangoes during ripening (storage period). The PME activity was statistically different $(\mathrm{p} \leq 0.05)$ between 1 MCP-treated and untreated mangoes along this study. PME activity started at 0.52 and ended at 0.29 units $\mathrm{mg}^{-1}$ protein in untreated mango fruit, whereas 1-MCPtreated mangoes started at 0.44 units $\mathrm{mg}^{-1}$ protein and ended with 0.26 units $\mathrm{mg}^{-1}$ protein.

\section{DISCUSSION}

In a previous report (Osuna-Garcia et al., 2005), 1MCP applied at $300 \mathrm{~nL} \mathrm{~L}^{-1}$ dose (during $20 \mathrm{~h}$ at $13^{\circ} \mathrm{C}$ ) barely affected "Kent" mango's respiration rate and ethylene production and did not affect either TSS or pulp color. However, treatment with 1-MCP retarded firmness losses of mango. A report for "Dashehari" mango showed that 1-MCP treatment reduced sugars and reduced firmness losses of mangoes as compared to untreated ones (Singh et al., 2007). The fact that 1-MCP has different effects on appearance and other quality attributes could be due to the variety and maturity stage of the mango used, as well as on the concentration and time of exposure to 1-MCP.

Reported concentrations of 1-MCP applied to mango fruits are variable and it is necessary to make trial and error experiments to define appropriate amounts for the different cultivars. There is a report of a higher concentration $\left(25000 \mathrm{~nL} \mathrm{~L}^{-1}\right)$ of $1-\mathrm{MCP}$ applied to "Kensington pride" mango during $14 \mathrm{~h}$; although this amount prolonged mango shelf life for up to 5 days, it also enhanced stem rots in this fruit (Hofman et al., 2001). In contrast, when another mango cultivar was treated during $12 \mathrm{~h}$ with $1-\mathrm{MCP}$ at concentrations of $1000-100,000$ or $200,000 \mathrm{~nL} \mathrm{~L}^{-1}$, their ripening was suppressed to a higher extent (Jiang and Joyce, 2000). According to these results, we can conclude that sensitivity of mango fruit to $1-\mathrm{MCP}$ is an important factor that has to be considered in order to optimize its application. These results suggest that application and evaluation of different concentrations, temperature and time of exposure to this compound to obtain the best conditions for each cultivar are needed.

Ornelas-Paz et al. (2007) reported that $\beta$-carotene content of different mango cultivars ranges from 0.4$2.8 \mathrm{mg} 100 \mathrm{~g}^{-1}$. These authors reported that "Haden" mango has the highest carotene content with $3 \mathrm{mg} 100$ $\mathrm{g}^{-1}$ while "Kent" cultivar only has $1 \mathrm{mg} 100 \mathrm{~g}^{-1}$. Differences in $\beta$-carotene content observed in mango could be attributed mainly to differences in maturation. The "Kent" mangoes used in the study by Ornelas-Paz et al. (2007) had a TSS of 16, whereas mangoes used in the present study, initially had a TSS of 12 , reaching a final TSS concentration of 20 , after 2 weeks at $20^{\circ} \mathrm{C}$. The $\beta$-carotene content of 1 -MCP treated mangoes stored for 6 and 12 days at $20^{\circ} \mathrm{C}$ was higher and statistically different $(\mathrm{p} \leq 0.05)$ from the content of untreated mangoes. This result suggests that 1-MCP treatment helps to keep the nutritional value of mango fruit.

The reduced losses of AA content in mango "Kent" are in agreement with a report for "Keitt" mango by Gomez and Lajolo (2008) and for "Tainong" mango (Wang et al., 2009). The study of compounds that affect AA content in edible parts of plants is important since it 
could lead to a better nutritional value and antioxidant capacity of food crops. Treatment of "Tommy Atkins" mangoes with $500 \mathrm{~nL} \mathrm{~L}^{-1}$ of 1-MCP kept fruits with higher vitamin C contents (Alves et al., 2004). These results demonstrate that this postharvest technology is useful in keeping the nutritional quality of this tropical fruit. At the moment, the mechanisms that control AA contents in tropical fruits are still unknown; therefore future studies on AA biosynthesis will lead to elucidate these mechanisms.

Yashoda et al. (2007) reported a gradual increase in the activity of PG in ripe "Alphonso" mango. The reduction of PG activity on 1-MCP treated "Kent" mangoes suggests that the biosynthesis or stability of this enzyme is affected by the gas; however, further studies are needed to know the mechanism involved in this event. Yashoda et al. (2007) reported similar PME activity in "Alphonso" mango during ripening. The PME activity shown by the 1-MCP-treated mangoes was lower than the untreated fruits, suggesting that such mechanism does occur.

\section{CONCLUSION}

As a conclusion, in this study, 1-MCP did not delay ripening and softening during postharvest in the study hereby and the main effect of 1-MCP was in reducing the losses of ascorbic acid during the postharvest stage; this by itself represents an important effect to take its use into consideration. Possible reasons for lack of effect in firmness are the dose and time of exposure. However, if a small dose is able to prevent nutritional value, it is worth investigating these effects. It would be of great interest to investigate whether this 1-MCP treatment of mangoes leads to a longer shelf life.

\section{ACKNOWLEDGEMENT}

We thank CONACyT for Grants 40466 and 60950 to Dr. M.A. Islas-Osuna. We also thank Drs. Adriana Muhlia and Rogerio Sotelo for critical reading of the manuscript. Norma A. Stephens-Camacho thanks CONACyT for a graduate scholarship.

\section{REFERENCES}

Alves, R.E., H.A.C. Filgueiras, A.S. Almeida, M.E.C. Pereira and F.M. Cocozza et al., 2004. Postharvest ripening of 'Tommy Atkins' mangoes on two maturation stages treated with 1-MCP. ISHS Acta Horticult., 645: 627-632.

Argenta, L.C., X.T. Fan and J.P. Mattheis, 2003. Influence of 1-methylcyclopropene on ripening, storage life and volatile production by d'Anjou cv. pear fruit. J. Agric. Food Chem., 51: 3858-3864. DOI: $10.1021 / \mathrm{jf034028g}$
Banjongsinsiri, P., S. Kenney and L. Wicker, 2004. Texture and distribution of pectic substances of mango as affected by infusion of pectin methylesterase and calcium. J. Sci. Food Agric., 84: 1493-1499. DOI: 10.1002/jsfa. 1782

Bassetto, E., A.P. Jacomino, A.L. Pinheiro and R.A. Kluge, 2005. Delay of ripening of 'Pedro Sato' guava with 1-methylcyclopropene. Postharvest Biol. Technol., 35: 303-308. DOI: 10.1016/j.postharvbio.2004.08.003

Blankenship, S.M. and J.M. Dole, 2003. 1methylcyclopropene: a review. Postharvest Biol. Technol., 28: 1-25. DOI: 10.1016/S09255214(02)00246-6

Boquete, E.J., G.D. Trinchero, A.A. Fraschina, F. Vilella and G.O. Sozzli, 2004. Ripening of Hayward kiwifruit treated with 1-methylcyclopropene after cold storage. Postharvest Biol. Technol., 32: 57-65. DOI: $10.1016 /$ j.postharvbio.2003.09.013

Bradford, M.M., 1976. Rapid and sensitive method for quantitation of microgram quantities of protein utilizing principle of protein-dye binding. Anal. Biochem., 72: 248-254. DOI: 10.1016/00032697(76)90527-3.

Brummell, D.A. and M.H. Harpster, 2001. Cell wall metabolism in fruit softening and quality and its manipulation in transgenic plants. Plant Mol. Biol., 47: 311-340. DOI: 10.1023/A:1010656104304.

Bregoli, A.M., V. Ziosi, S. Biondi, A. Rasori and M. Ciccioni et al., 2005. Postharvest 1methylcyclopropene application in ripening control of Stark Red Gold nectarines: Temperaturedependent effects on ethylene production and biosynthetic gene expression, fruit quality and polyamine levels. Postharvest Biol. Technol., 37: 111-121. DOI: 10.1016/j.postharvbio.2005.04.006

Cadena-Iniguez, J., L. Arevalo-Galarza, L.M. RuizPosadas, J.F. Aguirre-Medina and M. SotoHernandez et al., 2006. Quality evaluation and influence of 1-MCP on Sechium edule (Jacq.) Sw. fruit during postharvest. Postharvest Biol. Technol., $\quad 40$ : 170-176. $\quad$ DOI: 10.1016/j.postharvbio.2005.12.013

Caprioli, I., M.T. Lafuente, M.J. Rodrigo and F. Mencarelli, 2009. Influence of postharvest treatment on quality, carotenoids and abscisic acid content of stored "Spring Belle" peach (Prunus persica) fruit. J. Agric. Food Chem., 57: 7056-7063. DOI: 10.1021/jf900565g

Defilippi, B.G., A.M. Dandekar and A.A. Kader, 2004. Impact of suppression of ethylene action or biosynthesis on flavor metabolites in apple (Malus domestica Borkh) fruits. J. Agric. Food Chem., 52: 5694-5701. DOI: 10.1021/jf049504x 
Del Monte, C.F., J.J. Tadeo, A.R. Elesbao, F.H.A. Cunha and P.M.E. Canto, 2004. Respiration rate and chemical characteristics of cold stored "Tommy Atkins" mangoes influenced by 1-MCP and modified atmosphere packaging. Acta Horticult., 645: 645-650.

Doner, L.W. and K.B. Hicks, 1981. High performance liquid chromatographic separation of ascorbic-acid, erythorbic acid, dehydroascorbic acid, dehydroerythorbic acid, diketogulonic acid and diketogluconic acid. Anal. Biochem., 115: 225-230. DOI: 10.1016/0003-2697(81)90550-9

Dong, L., H.W. Zhou, L. Sonego, A. Lers and S. Lurie, 2001. Ripening of 'Red Rosa' plums: Effect of ethylene and 1-methylcyclopropene. Aust. J. Plant Physiol., 28: 1039-1045. DOI: 10.1071/PP00149

Dong, L., S. Lurie and H.W. Zhou, 2002. Effect of 1methylcyclopropene on ripening of 'Canino' apricots and 'Royal Zee' plums. Postharvest Biol. Technol., 24: 135-145. DOI: 10.1016/S09255214(01)00130-2

Ekman, J.H., M. Clayton, W.V. Biasi and E.J. Mitcham, 2004. Interactions between 1-MCP concentration, treatment interval and storage time for 'Bartlett' pears. Postharvest Biol. Technol., 31: 127-136. DOI: 10.1016/j.postharvbio.2003.07.002

Ergun, M., S.T. Sargent, A.J. Fox, J.H. Crane and D.J. Huber, 2005. Ripening and quality responses of mamey sapote fruit to postharvest wax and 1methylcyclopropene treatments. Postharvest Biol. Technol., 36: 127-134. DOI: 10.1016/j.postharvbio.2004.12.002

Feng, X.Q., A. Apelbaum, E.C. Sisler and R. Goren, 2000. Control of ethylene responses in avocado fruit with 1-methylcyclopropene. Postharvest Biol. Technol., 20: 143-150. DOI: 10.1016/S09255214(00)00126-5

Giovannoni, J.J., 2004. Genetic regulation of fruit development and ripening. Plant Cell, 16: 170-180. DOI: $10.1105 /$ tpc.019158

Gomez, M. and F. Lajolo, 2008. Ascorbic acid metabolism in fruits: activity of enzymes involved in synthesis and degradation during ripening in mango and guava. J. Sci. Food Agric., 88: 756-762. DOI: $10.1002 /$ jsfa.3042

Gross, K.C., 1982. A rapid and sensitive spectrophotometric method for assaying polygalacturonase using 2-cyanoacetamide. Hortscience, 17: 933-934.

Harima, S., R. Nakano, S. Yamauchi, Y. Kitano and Y. Yamamoto et al., 2003. Extending shelf-life of astringent persimmon (Diospyros kaki Thunb.) fruit by 1-MCP. Postharvest Biol. Technol., 29: 319-324. DOI: 10.1016/S0925-5214(03)00058-9
Hiwasa, K., Y. Kinugasa, S. Amano, A. Hashimoto and R. Nakano et al., 2003. Ethylene is required for both the initiation and progression of softening in pear (Pyrus communis L.) fruit. J. Exp. Bot., 54: 771-779. DOI: 10.1093/jxb/erg073

Hofman, P.J., M. Jobin-Decor, G.F. Meiburg, A.J. Macnish and D.C. Joyce, 2001. Ripening and quality responses of avocado, custard apple, mango and papaya fruit to 1-methylcyclopropene. Aust. J. Exp. Agric., 41: 567-572. DOI: 10.1071/EA00152

Jiang, Y. and D.C. Joyce, 2000. Effects of 1methylcyclopropene alone and in combination with polyethylene bags on the postharvest life of mango fruit. Ann. Applied Biol., 137: 321-327. DOI: 10.1111/j.1744-7348.2000.tb00073.x

Jiang, Y.M., D.C. Joyce and L.A. Terry, 2001. 1Methylcyclopropene treatment affects strawberry fruit decay. Postharvest Biol. Technol., 23: 227-232. DOI: 10.1016/S0925-5214(01)00123-5

Koch, J.L. and D.J. Nevins, 1989. Tomato fruit cellWall: 1. Use of purified tomato polygalacturonase and pectinmethylesterase to identify developmental-changes in pectins. Plant Physiol., 91: 816-822. PMID: 16667142

Kondo, S., S. Setha, D.R. Rudell, D.A. Buchanan and J.P. Mattheis, 2005. Aroma volatile biosynthesis in apples affected by 1-MCP and methyl jasmonate. Postharvest Biol. Technol., 36: 61-68. DOI: 10.1016/j.postharvbio.2004.11.005

Lohani, S., P.K. Trivedi and P. Nath, 2004. Changes in activities of cell wall hydrolases during ethyleneinduced ripening in banana: Effect of 1-MCP, ABA and IAA. Postharvest Biol. Technol., 31: 119-126. DOI: 10.1016/j.postharvbio.2003.08.001

Mao, L.C., Y. Karakurt and D.J. Huber, 2004. Incidence of water-soaking and phospholipid catabolism in ripe watermelon (Citrullus lanatus) fruit: Induction by ethylene and prophylactic effects of 1-methylcyclopropene. Postharvest Biol. Technol., 33: 1-9. DOI: 10.1016/j.postharvbio.2003.12.007

Martinez-Romero, D., E. Dupille, F. Guillen, J.M. Valverde and M. Serrano et al., 2003. 1Methylcyclopropene increases storability and shelf life in climacteric and nonclimacteric plums. J. Agric. Food Chem., 51: 4680-4686. DOI: 10.1021/jf034338z

Mejia, L.A., E. Hudson, E.G. Demejia and F. Vazquez, 1988. Carotenoid content and vitamin A activity of some common cultivars of Mexican peppers (Capsicum-annuum) as determined by HPLC. J. Food Sci., 53: 1448-1451. DOI: 10.1111/j.13652621.1988.tb09295x 
Menniti, A.M., R. Gregori and I. Donati, 2004. 1methylcyclopropene retards postharvest softening of plums. Postharvest Biol. Technol., 31: 269-275. DOI: 10.1016/j.postharvbio.2003.09.009

Mwaniki, M.W., F.M. Mathooko, M. Matsuzaki, K. Hiwasa and A. Tateishi et al., 2005. Expression characteristics of seven members of the betagalactosidase gene family in 'La France' pear (Pyrus communis L.) fruit during growth and their regulation by 1-methylcyclopropene during postharvest ripening. Postharvest Biol. Technol., 36: 253-263. DOI: 10.1016/j.postharvbio.2005.02.002

Ornelas-Paz, J.J., E.M. Yahia and A.A. Gardea-Bejar, 2007. Identification and quantification of xanthophyll esters, carotenes and tocopherols in the fruit of seven Mexican mango cultivars by liquid chromatography atmospheric pressure chemical ionization-time of flight mass spectrometry. J. Agric. Food Chem., 55: 6628-6635. PMID: 17625873

Osuna-Garcia, J.A., J.A. Beltran and M.A. UriasLopez, 2005. Effect of 1-Methylcyclopropene (1MCP) on shelf life and quality of exporting mango. Revista Fitotecnia Mexicana, 28: 271-278.

Saltveit, M.E., 1999. Effect of ethylene on quality of fresh fruits and vegetables, Postharvest Biol. Technol., 15: 279-292. DOI: 10.1016/S09255214(98)00091-X.

Selvarajah, S., A.D. Bauchot and P. John, 2001. Internal browning in cold-stored pineapples is suppressed by a postharvest application of 1methylcyclopropene. Postharvest Biol. Technol., 23: 167-170. DOI: 10.1016/S0925-5214(01)00099-0

Singh, R., P. Singh, N. Pathak, V. Singh and U. Dwivedi, 2007. Modulation of mango ripening by chemicals: Physiological and biochemical aspects. Plant Growth Regul., 53: 137-145. DOI: 10.1007/s 10725-007-9211-1
Sisler, E.C. and M. Serek, 1997. Inhibitors of ethylene responses in plants at the receptor level: recent developments. Physiol. Plantarum, 100: 577-582. DOI: 10.1111/j.1399-3054.1997.tb03063.x.

Wang, B.G., W.B. Jiang, H.X. Liu, L. Lin and J.H. Wang, 2006. Enhancing the postharvest qualities of mango fruit by vacuum infiltration treatment with 1-methylcyclopropene. J. Horticult. Sci. Biotechnol., 81: 163-167.

Wang, B., J. Wang, X. Feng, L. Lin, Y. Zhao and W. Jiang, 2009. Effects of 1-MCP and exogenous ethylene on fruit ripening and antioxidants in stored mango. Plant Growth Regul., 57:185-192. DOI: $10.1007 / \mathrm{s} 10725-008-9335-y$

Wang, K.L.C., H. Li and J.R. Ecker, 2002. Ethylene biosynthesis and signaling networks. Plant Cell, 14: S131-S151. DOI: 10.1105/tpc.001768

Watada, A. and D. Massie, 1981. A compact automatic system for measuring $\mathrm{CO}_{2}$ and $\mathrm{C}_{2} \mathrm{H}_{4}$ evolution by harvest horticultural crops. Hortic. Sci., 16: 39-41.

Watkins, C.B., 2006. The use of 1-Methylcyclopropene (1-MCP) on fruits and vegetables. Biotechnol. Adv., 24: 389-409. DOI: 10.1016/j.biotechadv.2006.01.005

Watkins, C.B., 2002. Ethylene Synthesis, Mode of Action, Consequences and Control. In: Fruit Quality and its Biological Basis, Knee, M. (Ed.), CRC Press USA, ISBN: 0849397812, pp: 180-224.

Wicker, L., R.J. Braddock and M. Vassallo, 1987. Effect of assay temperature on activity of citrus pectinesterase in fresh orange juice. J. Food Sci., 52: $\quad 378-380$. DOI: $10.1111 /$ j.13652621.1987.tb06618.x

Yashoda, H., T. Prabha and R. Tharanathan, 2007. Mango ripening-Role of carbohydrases in tissue softening. Food Chem., 102: 691-698. DOI: 10.1016/j.foodchem.2006.06.001 